\title{
43. OCEAN CRUST-SEA WATER INTERACTION: SITES 417 AND 418
}

\author{
S.R. Hart and H. Staudigel, ${ }^{1}$ Department of Earth and Planetary Sciences, Massachusetts Institute of Technology, \\ Cambridge, Massachusetts
}

\begin{abstract}
Ages of vein mineral deposition in Holes $417 \mathrm{~A}$ and $418 \mathrm{~A}$ have been determined both by $\mathrm{Rb}-\mathrm{Sr}$ isochron techniques on vein smectites and by comparison of ${ }^{87} \mathrm{Sr} /{ }^{86} \mathrm{Sr}$ ratios of vein calcites with the known variations of sea water ${ }^{87} \mathrm{Sr} /{ }^{86} \mathrm{Sr}$ with time. Both techniques give ages which are the same as the age of crust formation within the analytical uncertainties $( \pm 10 \mathrm{~m} . \mathrm{y}$.). The vein smectites are shown to be mixtures of a high-alkali smectite with the basalt host. Insofar as the $\mathrm{Rb} / \mathrm{Sr}$ data indicate that the smectites have been closed systems since crystallization, the alkali abundances of smectites may provide a way of determining the paleoalkali contents of sea water.
\end{abstract}

\section{INTRODUCTION}

Sea water is believed to circulate through the oceanic crust as a thermally driven convection process (Talwani et al., 1971; Lister, 1972, 1974; Williams et al., 1974; Wolery and Sleep, 1976; Spooner, 1976). This process has considerable potential for creating large chemical fluxes between oceanic and crustal reservoirs, because of both the mass of crust involved and the chemically reactive nature of heated sea water. At present, three uncertainties prevent quantitative evaluation of this interaction mechanism: (1) the depth to which sea-water circulation extends in the crust, (2) the duration of the circulation, and (3) the lack of systematic chemical information on the deepest drill holes available. We will present data here which show that circulation is important only for some $10 \mathrm{~m} . \mathrm{y}$. after crust formation, that circulation clearly extends to at least 500 meters depth, and that sea-water interaction with this upper crustal layer may be a dominant control for the alkali-metal budget of sea water.

\section{DURATION OF CIRCULATION}

Veins and fractures filled with carbonates and clay minerals are ubiquitous in the basaltic ocean crust. Typically having thicknesses of a few $\mathrm{mm}$ and spacings of some tens of $\mathrm{cm}$, these veins are undoubtedly the pathways for local distribution of circulating fluids (sea water). Larger scale distribution may also take place through the highly permeable rubble and breccia zones which are common in the oceanic crust. Since the smaller scale veins and fractures are probably the most important in controlling chemical fluxes, we have dated the deposition times of minerals in these veins.

Smectites were separated from eight small veins in Hole 418A (sub-basement depths of 70 to $544 \mathrm{~m}$ ), and one celadonite was separated from a vein in Hole $417 \mathrm{~A}$ at 60

\footnotetext{
${ }^{1}$ Present address: Ruhr-Universität Bochum, Institut für Mineralogie Lehrstuhl für Petrologie, D-463 Bochum, postfach 2148, West Germany.
}

meters depth. All smectites analyzed have expandable montmorillonite structures. As to composition, they are saponites or nontronites depending on their $\mathrm{Mg} / \mathrm{Fe}$ ratio. Microprobe analyses of some of these samples are reported by Robinson (this volume). Some samples show transitions in composition toward celadonite. The samples were handpicked to be as free as possible of wall rock basalt, and analyzed for $\mathrm{K}, \mathrm{Rb}, \mathrm{Cs}, \mathrm{Sr}, \mathrm{Ba}$, and ${ }^{87} \mathrm{Sr} /{ }^{86} \mathrm{Sr}$. The results are given in Table 1 , and the $\mathrm{Rb} / \mathrm{Sr}$ data plotted in the oceanic crust. Since the smaller scale veins and fractures are probably the most important in controlling chemical fluxes, we have dated the deposition times of minerals in these veins.

Smectites were separated from eight small veins in Hole 418A (sub-basement depths of 70 to $544 \mathrm{~m}$ ), and one celadonite was separated from a vein in Hole $417 \mathrm{~A}$ at 60 meters depth. All smectites analyzed have expandable montmorillonite structures. As to composition, they are saponites or nontronites depending on their $\mathrm{Mg} / \mathrm{Fe}$ ratio. Microprobe analyses of some of these samples are reported by Robinson (this volume). Some samples show transitions in composition toward celadonite. The samples were handpicked to be as free as possible of wall rock basalt, and analyzed for $\mathrm{K}, \mathrm{Rb}, \mathrm{Cs}, \mathrm{Sr}, \mathrm{Ba}$, and ${ }^{87} \mathrm{Sr} /{ }^{86} \mathrm{Sr}$. The results are given in Table 1 , and the $\mathrm{Rb} / \mathrm{Sr}$ data plotted on an isochron diagram in Figure 1. There is some scatter in these data, and regression analysis (York, 1966) of various subsets of the data gives the following results:

\begin{tabular}{lll}
\hline \multicolumn{1}{c}{ Data Set } & Age (m.y.) & Initial Ratio \\
\hline All samples & $111.1 \pm 6.6$ & $0.70615 \pm 23$ \\
Excluding Section $76-2$ & $109.8 \pm 5.0$ & $0.70633 \pm 19$ \\
Excluding Section 29-3 & $112.3 \pm 10.7$ & $0.70614 \pm 27$ \\
Excluding Sections 29-3 and 76-2 & $109.7 \pm 8.3$ & $0.70633 \pm 22$ \\
(errors are $\pm 2 \sigma$ ) & & \\
\hline
\end{tabular}

First, it should be noted that all of the regressions give about the same age, and that this age (110-112 m.y.) is in 
TABLE 1

$\mathrm{K}, \mathrm{Rb}, \mathrm{Cs}, \mathrm{Sr}, \mathrm{Ba}$ Contents and ${ }^{87} \mathrm{Sr} /{ }^{86} \mathrm{Sr}$ Ratios of Leg 53 Smectites ${ }^{\mathrm{a}}$

\begin{tabular}{lclccccc}
\hline $\begin{array}{c}\text { Sample } \\
\text { (Interval in cm) }\end{array}$ & $\begin{array}{c}\text { Sub-Baseinent } \\
\text { Depth (m) }\end{array}$ & $\mathrm{K}(\%)$ & $\mathrm{Rb}(\mathrm{ppm})$ & $\mathrm{Cs}(\mathrm{ppm})$ & $\mathrm{Sr}(\mathrm{ppm}){ }^{\mathrm{b}}$ & $\mathrm{Ba}(\mathrm{ppm})$ & ${ }^{87} \mathrm{Sr}^{86} \mathrm{Sr}^{\mathrm{c}}$ \\
\hline 418A-26-3, 100 & 70.5 & - & 9.80 & - & 48.25 & - & $0.70787 \pm 7$ \\
418A-41-3,100 & 184.0 & 3.49 & 109.3 & 1.807 & 52.94 & 6.49 & $0.71616 \pm 18$ \\
418A-51-1,28 & 263.3 & 0.0722 & 0.521 & 0.0088 & 41.76 & 1.992 & $0.70671 \pm 11$ \\
418A-56-5, 129 & 316.0 & 1.852 & 73.0 & 1.088 & 58.32 & 5.14 & $0.71136 \pm 14$ \\
418A-59-1, 102 & 338.4 & 0.1422 & 4.845 & 0.0779 & 59.32 & 1.996 & $0.70622 \pm 11$ \\
418A-66-1, 38 & 395.0 & 0.1833 & 3.916 & 0.1156 & 52.40 & 3.176 & $0.70652 \pm 8$ \\
418A-66-6, 60 & 404.0 & 0.270 & 9.75 & - & - & 5.67 & - \\
418A-76-2, 120 & 470.0 & 0.2637 & 10.18 & 0.202 & 79.68 & 2.506 & $0.70578 \pm 22$ \\
418A-86-5, 20 & 543.6 & 0.3225 & 9.59 & 0.1105 & 48.02 & 2.042 & $0.70708 \pm 31$ \\
417A-29-3, 132 & 60.3 & 6.48 & 226.3 & 1.198 & 11.09 & 1.120 & $0.79848 \pm 43$ \\
\hline
\end{tabular}

${ }^{a}$ Analytical techniques as described in Hart and Brooks (1977).

b Content of "normal" strontium, calculated for ${ }^{87} \mathrm{Sr} / 86 \mathrm{Sr}=0.7070$.

${ }^{c}$ Values are relative to 0.70800 for the $\mathrm{E}$ and A standard. Errors are $\pm 2 \sigma$, multiplied by $10^{5}$.

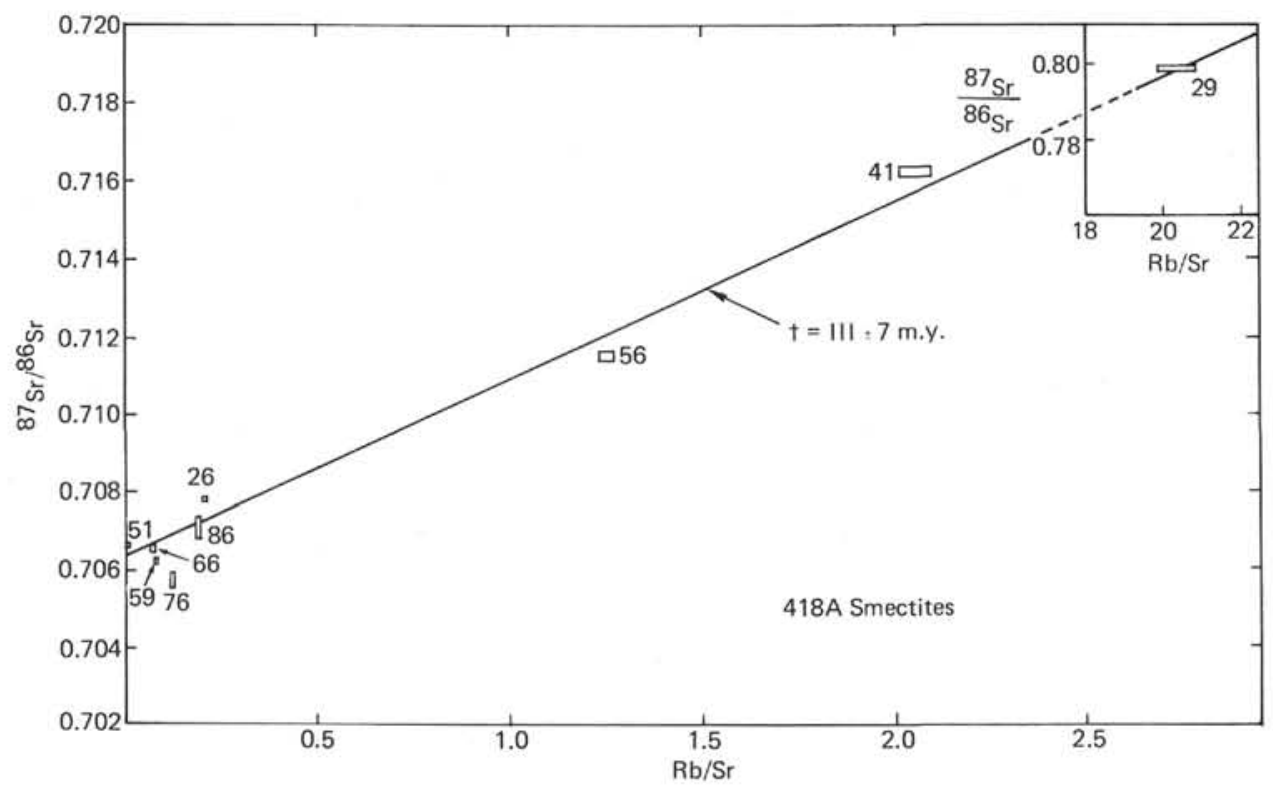

Figure 1. Rb-Sr isochron diagram for Leg 53 smectites. Abscissa is $\mathrm{Rb} / \mathrm{Sr}$ weight ratio, derived from measured $87 \mathrm{Rb} / 86 \mathrm{Sr}$ ratio by the factor $1 / 2.894$. Analytical uncertainty on each point is represented by the size of rectangle. Abbreviated sample numbers (Table 1) are indicated for each point. Isochron parameters are calculated using the York I regression (York, 1966), where isochron errors depend solely on the scatter of the data.

good agreement with the age of $110 \mathrm{~m} . \mathrm{y}$. for crust formation (Flower, Salisbury, et al., 1977). Secondly, an age may be calculated for the celadonite by itself; this age is relatively insensitive to the initial ratio because of the radiogenic nature of the celadonite. The use of an initial ratio equivalent to the calcite ${ }^{87} \mathrm{Sr} /{ }^{86} \mathrm{Sr}$ values reported below (0.70738) yields an age of $108 \pm 2 \mathrm{~m}$.y. If an initial ratio of 0.7063 is used (from Figure 1), the age would be $110 \pm 2 \mathrm{~m} . \mathrm{y}$. This evidence suggests that vein mineral formation at these sites is essentially contemporaneous with crust formation. Furthermore, the independent celadonite age for Hole $417 \mathrm{~A}$ is the same as the smectite ages from Hole 418A. This suggests that vein circulation in Hole $417 \mathrm{~A}$, which was drilled on a topographic basement high, was not of greater duration than that in Hole 418A, contrary to the proposal of Donnelly, Francheteau, et al. (1977).

There is scatter in the smectite data of Figure 1 over and above that expected from analytical uncertainties. This could be caused either by the smectites having a nonuniform initial $\mathrm{Sr}$ isotope composition, or by open system behavior of $\mathrm{Rb}$ and/or $\mathrm{Sr}$ since the time of crystallization. Sea water $110 \mathrm{~m}$.y. ago had a ${ }^{87} \mathrm{Sr} /{ }^{86} \mathrm{Sr}$ ratio of 0.70738 (see below); if the smectites crystallized in equilibrium with this sea water, the isochron should show this initial ratio. In fact, the observed initial ratio is considerably lower $(\sim 0.7062)$, suggesting some admixture of basalt $\mathrm{Sr}(\sim 0.7030)$. Thus the smectites may have incorporated some basaltic precursors during crystallization, or crystallized not from 
sea water, but from fluids which had partly exchanged with basalt. To test these possibilities, the smectite data have been plotted on various mixing diagrams (Figures 2, 3, and 4). In $a^{87} \mathrm{Sr} /{ }^{86} \mathrm{Sr}$ versus $1 / \mathrm{Sr}$ diagram (Figure 2), mixing lines are linear. The smectites appear in a roughly linear alignment, with the samples lowest in Sr having the highest ${ }^{87} \mathrm{Sr} /{ }^{86} \mathrm{Sr}$, showing values which approach those expected of 110 m.y.-sea water $(\sim 0.7074$, note calcite data). The high-Sr end of the smectite line points, not at fresh basalt (taken to be the glasses lowest in ${ }^{87} \mathrm{Sr} /{ }^{86} \mathrm{Sr}$ ), but toward somewhat higher ${ }^{87} \mathrm{Sr} /{ }^{86} \mathrm{Sr}$ values (as could be represented by a whole rock-palagonite mixture). This diagram thus supports the interpretation of the smectites as being mixtures of a pure "sea water" smectite, and a "basaltic", component. That the basaltic component does not seem to be a "fresh" basalt suggests furthermore that the mixing process was not one which happened during initial smectite formation but more probably during our mechanical separation of the smectite; therefore, the basaltic contaminant was not "fresh"' basalt but previously altered basalt.

This mixing process can also be evaluated from the $\mathrm{K}$, $\mathrm{Rb}$, and $\mathrm{Cs}$ contents, plotted in Figures 3 and 4 . Here again, we see that the smectites form a good mixing array between some "pure", high alkali smectite and the basalt. The mixing line is drawn using world-average mid-ocean ridge basalt (MORB) as an end member, although we have shown elsewhere (Staudigel, et al., this volume) that the Leg 53 basalts are more depleted in alkalies than typical MORB. Thus, as noted above, the mixing does not seem to involve a "fresh" basalt end member, but one already partially altered. In Figures 3 and 4, alteration (palagonite, altered glass) of a highly depleted "fresh"' basalt, of the Leg 53 type, will move it toward higher $\mathrm{K}, \mathrm{Rb}$, and Cs contents; this would then provide a reasonable "altered" endmember to the smectite trend.

Refinement of the smectite $\mathrm{Rb} / \mathrm{Sr}$ dating techniques can involve either more careful mineral separation, so as to exclude basalt admixtures, or use of the various mixing parameters, such as considered here, to "correct-out" the basalt admixture. This latter technique is hindered by the fact that a single pure smectite end-member does not seem to exist. The mixing "order" of samples in Figure 2 is different from that in Figures 3 and 4, suggesting a decoupling of $\mathrm{Sr}$ from the alkalies in the formation of a pure smectite. The evidence from Figures 2, 3, and 4 for at least three-component mixing also supports interpretation of the $\mathrm{Rb} / \mathrm{Sr}$ results (Figure 5) as an isochron rather than a mixing line.

To provide additional support for the smectite $\mathrm{Rb}-\mathrm{Sr}$ age, we analyzed calcites from five veins in Hole 418A, taken at depths of 3 to 521 meters. The data are given in Table 2 . Because of the very low $\mathrm{Rb} / \mathrm{Sr}$ ratios of these calcites, their measured $\mathrm{Sr}$ isotope ratios are essentially "initial" ratios. The average of the five calcites is $0.70734 \pm 15(2 \sigma$

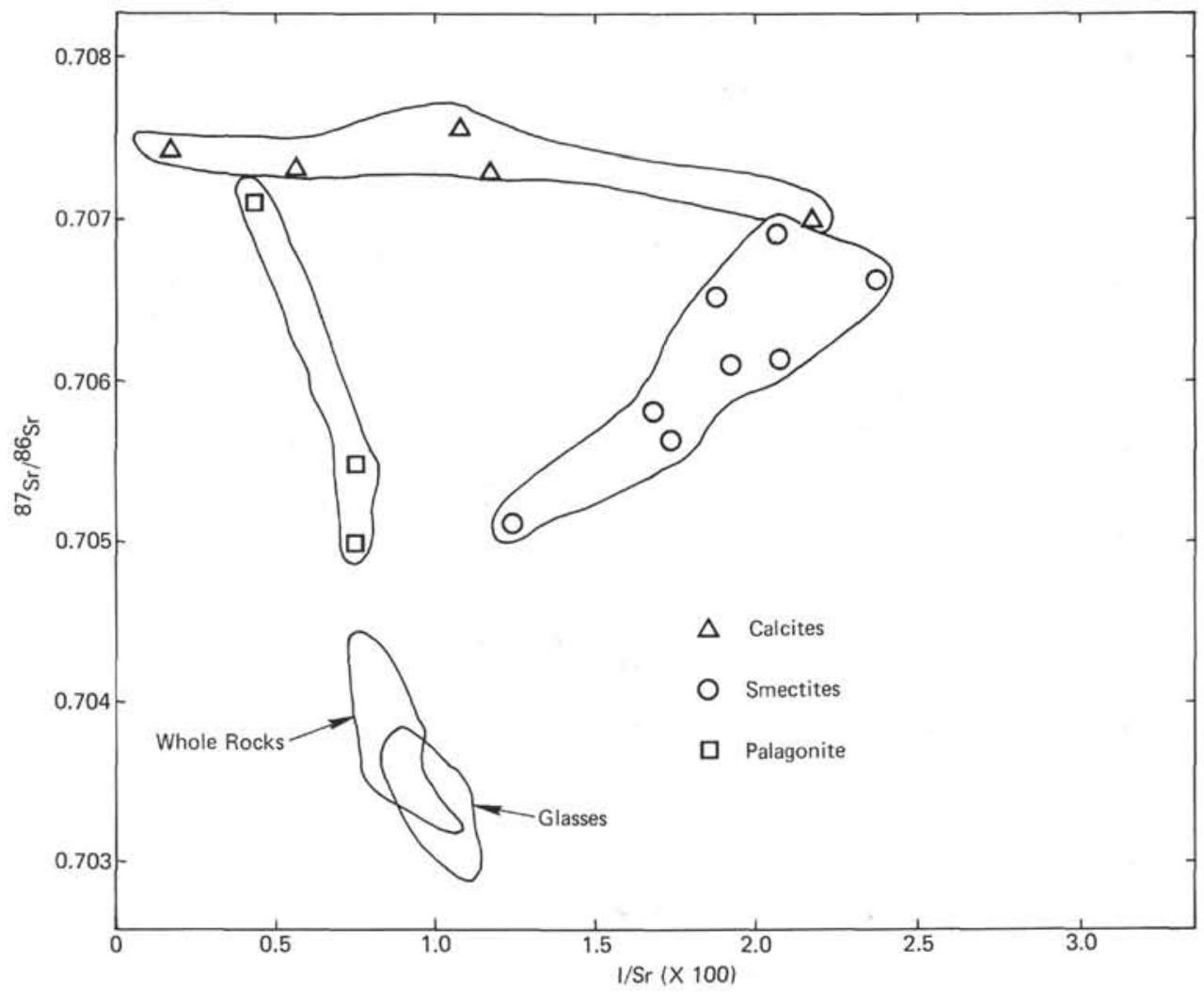

Figure 2. $87 \mathrm{Sr} / 86 \mathrm{Sr}$ versus $1 / \mathrm{Sr}$. Mixing lines on this plot will be linear. Smectite data are from Table 1, calcite data from Table 2; whole rock, palagonite, and glass data are from Staudigel et al. (1976). Note that smectites define a crude mixing array with a whole rock-palagonite mixture as one possible end member. The calcite data show only a very slight dependence of $87 \mathrm{Sr} / 86 \mathrm{Sr}$ on Sr content. 


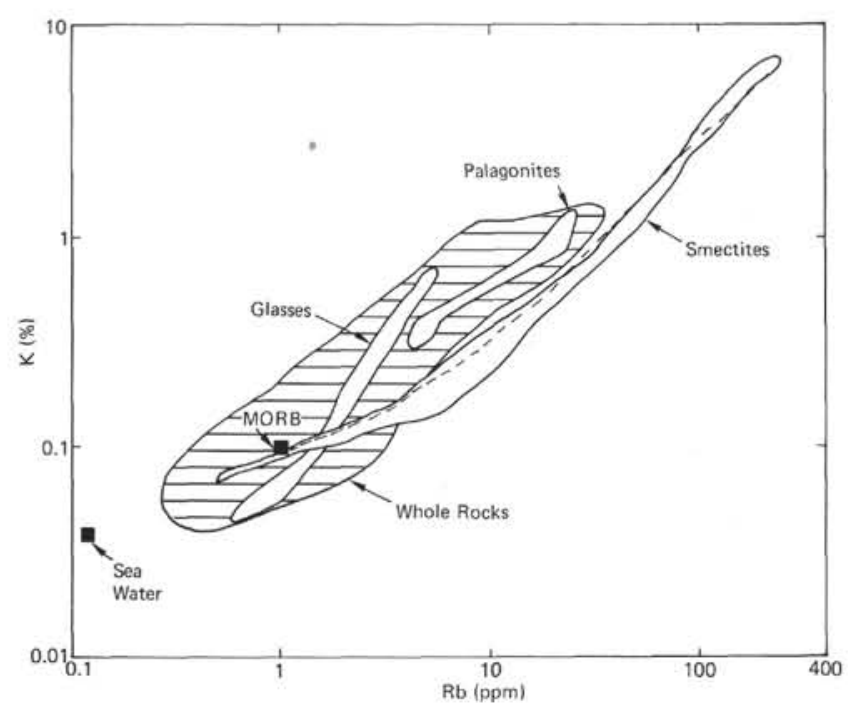

Figure 3. $K-R b$ concentrations in basalt glass, palagonite, smectite, and whole rocks from Hole 418A. Values for sea water and average worldwide spreading ridge basalt (MORB) are also shown. The smectite field represents mixtures of pure high-K smectite and basalt (MORB). The dashed line shows one such possible mixing line. The whole rocks can be thought of as variable mixtures of the four components $(M O R B+$ glass + palagonite + smectite). Whole rock, glass, and palagonite data are from Staudigel et al. (1976). standard error of the five analyses), with some variation beyond the experimental error. Assuming these calcites were deposited from circulating sea water, an age can be derived by comparing the calcite $\mathrm{Sr}$ value with the sea-water $\mathrm{Sr}$ isotope curve (Figure 6). The ${ }^{87} \mathrm{Sr} /{ }^{86} \mathrm{Sr}$ of sea water exhibits large and regular variations with time, and this variation has been relatively well established for the past $150 \mathrm{~m} . \mathrm{y}$. by analyses of fossil carbonate remains of known age. We fit the published data with a fourth-order polynomial curve; the scatter of data about this curve is probably analytical (assignment of fossil age and laboratory analysis of the $\mathrm{Sr}$ isotope ratio) and not a reflection of short-term variations in sea-water $\mathrm{Sr}$, although this presumption clearly needs testing. Within these uncertainties in the curve, it appears that calcite ages might be accurate to $\pm 10 \mathrm{~m}$.y. for relatively old ages ( $>100 \mathrm{~m} . \mathrm{y}$.) and to $\pm 5 \mathrm{~m} . \mathrm{y}$. for young ages $(<50 \mathrm{~m} . \mathrm{y}$.). Beyond $150 \mathrm{~m} . \mathrm{y}$., the curve is increasingly poorly constrained (Veizer and Compston, 1974; Brass, 1976), owing to poor fossil control and the possibility of $\mathrm{Sr}$ isotope exchange between the fossils and sediment.

The formal age for the five Hole 418A calcites, derived from the curve in Figure 5, is $115 \mathrm{~m} . \mathrm{y}$. This age agrees perfectly with the smectite $\mathrm{Rb} / \mathrm{Sr}$ age (111 m.y.), and the age of crust formation ( $110 \mathrm{~m} . \mathrm{y}$.$) , within the uncertainty of$ the calcite data and that of the sea-water curve $(\sim \pm 20 \mathrm{~m}$.y. combined uncertainty).

Regarding the variation of the calcite data $(0.7070$ to 0.7076 ), which is well beyond experimental precision, note that the highest value $(0.7076)$ is on a sample that is only 3

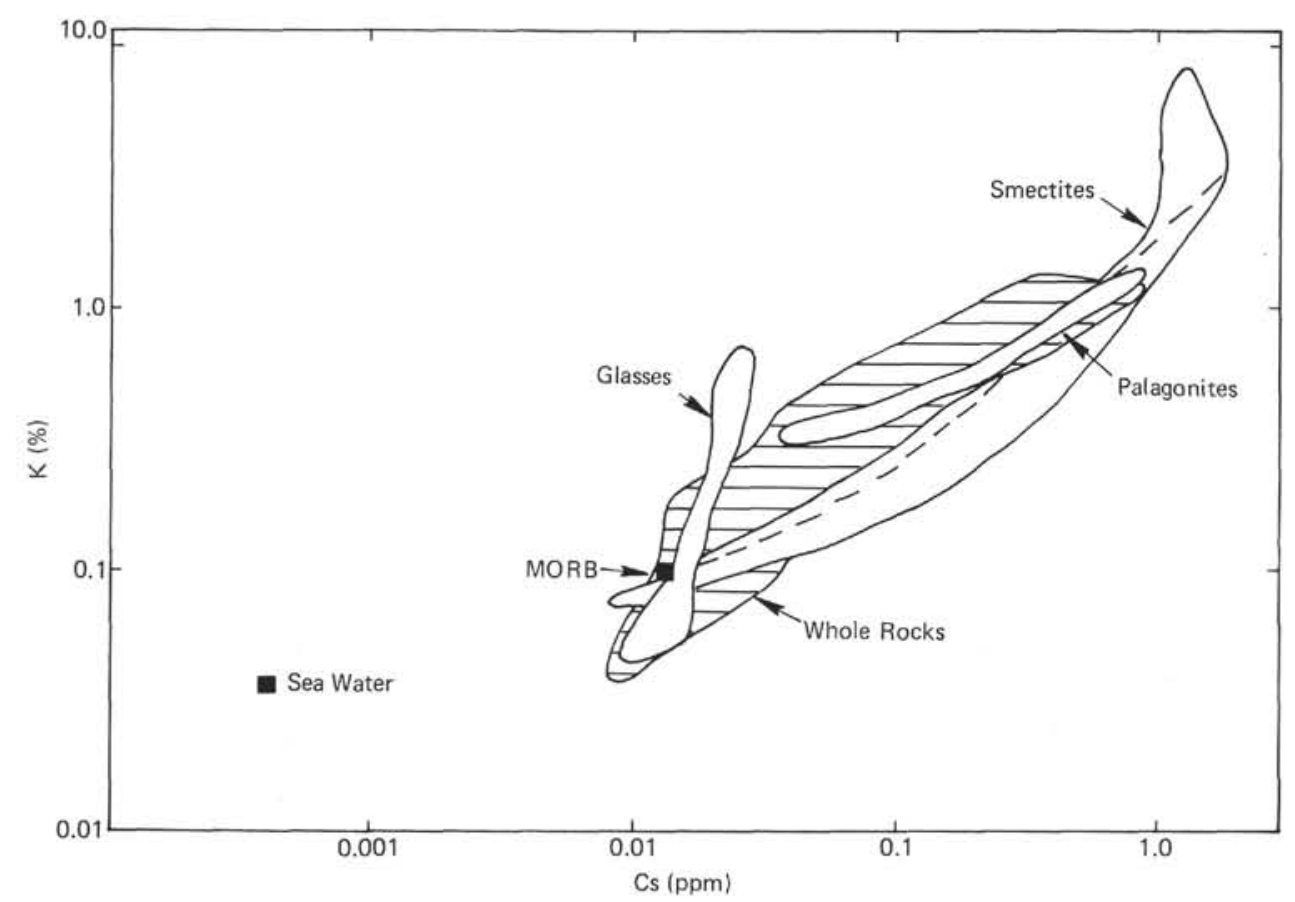

Figure 4. $K$-Cs concentrations in Hole $418 \mathrm{~A}$ materials. Values for sea water and average worldwide spreading ridge basalt (MORB) are also shown. The smectite field represents mixture of pure high-K smectite and basalt (MORB). The dashed line shows one such possible mixing line. The whole rocks can be thought of as variable mixtures of the four components (MORB + glass + palagonite + smectite). Whole rock, glass, and palagonite data are from Staudigel et al. (1976). 


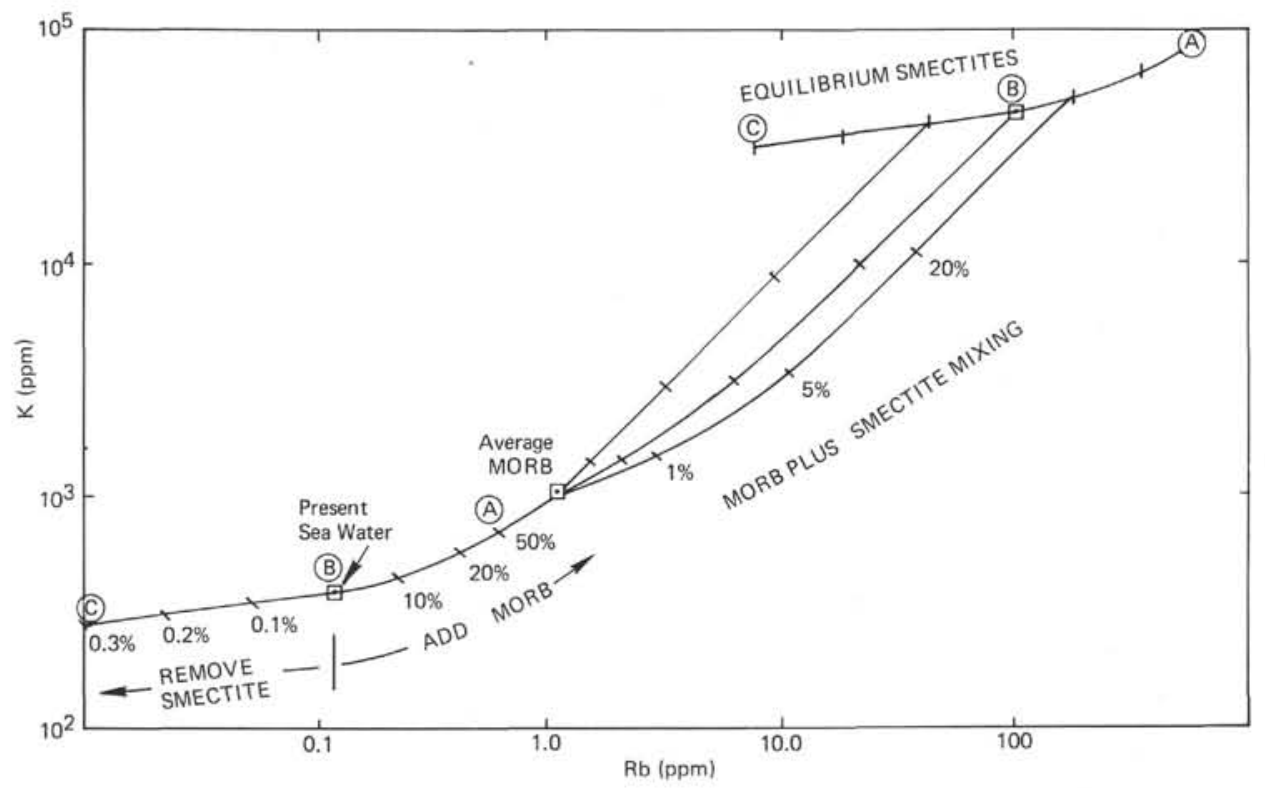

Figure 5. Schematic model showing the control of $K-R b$ in sea water by two competing reactions: dissolution of MORB in sea water (add MORB) and fractional crystallization of smectite from sea water (remove smectite). The smectites in equilibrium with possible sea waters along the two reaction trajectories are shown, based on estimated partition coefficients, smectite/sea water, of 114 for $K$ and 850 for Rb. Smectites usually occur with some MORB admixture and thus fall along mixing lines, three of which are shown. Each of these smectite-MORB mixing lines serves to define a unique $K / R b$ (and $K / C s$ ) for the sea water from which the smectites were crystallized. The numbers along the curves refer to the mixing fractions involved in each reaction.

TABLE 2

$\mathrm{K}, \mathrm{Rb}, \mathrm{Cs}, \mathrm{Sr}, \mathrm{Ba}$ Contents (ppm) and ${ }^{87} \mathrm{Sr} /{ }^{86} \mathrm{Sr}$ Ratios of Calcites ${ }^{\mathrm{a}}$

\begin{tabular}{lccccccc}
\hline $\begin{array}{c}\text { Sample } \\
\text { (Interval in cm) }\end{array}$ & $\begin{array}{c}\text { Sub-Basement } \\
\text { Depth }(\mathrm{m})\end{array}$ & $\mathrm{K}$ & $\mathrm{Rb}$ & $\mathrm{Cs}$ & $\mathrm{Sr}$ & $\mathrm{Ba}$ & ${ }^{87} \mathrm{Sr} /{ }^{86} \mathrm{Sr}^{\mathrm{b}}$ \\
\hline $418 \mathrm{~A}-15-2,40$ & 2.6 & 8.42 & 0.0937 & 0.00312 & 94.2 & 0.686 & $0.70760 \pm 9$ \\
$418 \mathrm{~A}-37-1,30$ & 156.5 & 21.12 & 0.2612 & 0.00115 & 86.3 & 1.027 & $0.70734 \pm 8$ \\
$418 \mathrm{~A}-45-2,131$ & 218.1 & 315.4 & 1.072 & 0.0194 & 177.6 & 1.424 & $0.70736 \pm 11$ \\
$418 \mathrm{~A}-59-1,102$ & 338.4 & 20.20 & 0.1105 & 0.00189 & 46.1 & 0.371 & $0.70700 \pm 5$ \\
$418 \mathrm{~A}-83-1,22$ & 520.7 & 413.3 & 1.481 & 0.0430 & 581.6 & 2.038 & $0.70741 \pm 6$ \\
$105-42-1,50$ & 4.6 & 35.1 & 0.052 & 0.00094 & 165.9 & 1.844 & $0.70692 \pm 7$ \\
$105-43-2,64$ & 8.8 & - & - & - & 132.8 & 2.118 & $0.70691 \pm 5$ \\
$332 \mathrm{~B}-6-1,130$ & 138.5 & 1400 & 2.94 & 0.0653 & 519.7 & 5.70 & $0.70912 \pm 4$ \\
$332 \mathrm{~B}-36-1,80$ & 450.5 & - & - & - & 370.3 & 13.68 & $0.70901 \pm 5$ \\
\hline
\end{tabular}

${ }^{a}$ Analytical techniques as described in Hart and Brooks (1977). Samples were dissolved in hot $2.5 \mathrm{~N}$ $\mathrm{HCl}$.

${ }^{b}$ Values are relative to 0.70800 for the $\mathrm{E}$ and A standard. Errors are $\pm 2 \sigma$, multiplied by $10^{5}$.

meters deep; the ${ }^{87} \mathrm{Sr} /{ }^{86} \mathrm{Sr}$ ratio of this sample may reflect more extended exchange with sea water (this calcite would give an individual "age" of 85 m.y.). The lowest calcite value $(0.7070)$ is also the sample with the lowest total $\mathrm{Sr}$ content, and thus would be most susceptible to contamination by other components. Note in Figure 2 that the calcites appear to lie on a slightly negative trend, with the low $\mathrm{Sr}$ sample lying near the smectite end-member of a mixing curve. In the future, we will use a different dissolution technique for calcite, so that no possible silicate contaminants get incorporated (these samples were dissolved in hot $2.5 \mathrm{~N} \mathrm{HCl}$ ). Finally, note that three of the calcites give $\mathrm{Sr}$ ratios which are the same within analytical error $(0.70737)$, and that this value agrees perfectly with $110-\mathrm{m} . \mathrm{y}$. sea-water $\mathrm{Sr}$.

An important assumption in our use of calcites to determine vein deposition ages is that the calcite crystallized from fluids of sea-water isotopic composition. Any exchange between circulating sea-water fluids and the basaltic crust will lower the ${ }^{87} \mathrm{Sr} /{ }^{86} \mathrm{Sr}$ values of the fluid, and this will lead to calcite "ages" which are too old. One direct test of this assumption is to look at calcites in very young crust, where the age of circulation can be given strict lower limits. For this purpose we analyzed two calcites from Hole 332B (Leg 37), drilled on 3.5 m.y. crust near the Mid-Atlantic Ridge. The calcites, from depths of 138 and 


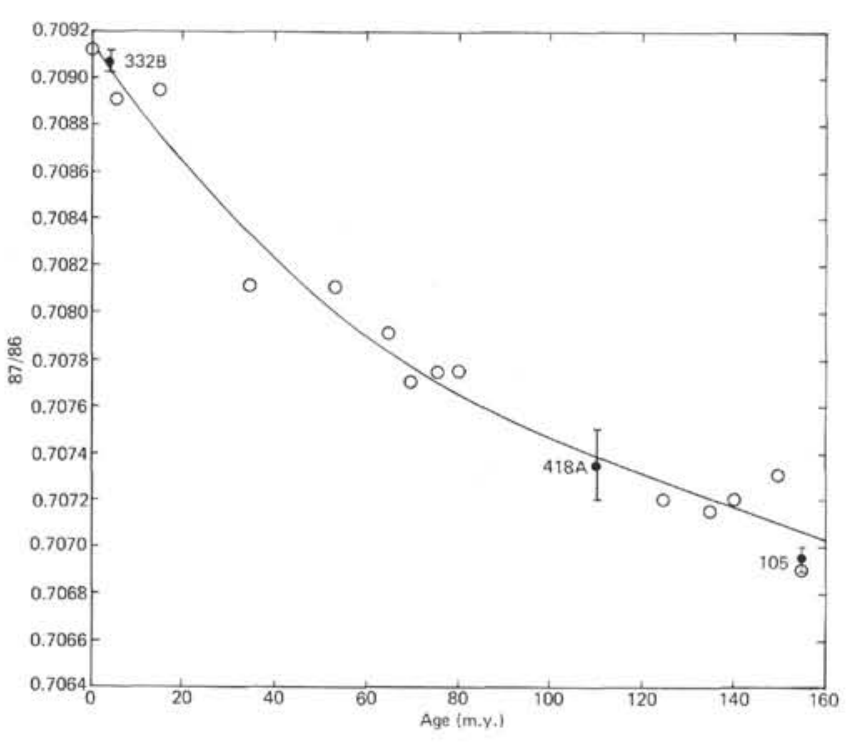

Figure 6. Variation of ${ }^{87} \mathrm{Sr} /{ }^{86} \mathrm{Sr}$ of sea water with time. Open circles denote the fossil data used to determine the curve (Peterman et al., 1970; Dasch and Biscaye, 1971; Brass, 1976; Veizer and Compston, 1974). The curve is a fourth-order polynomial: $(87 / 86) t=0.70912-2.7 x$ $10^{-5} t+1.2 \times 10^{-7} t^{2}-4.1 \times 10^{-11} t^{3}-9.2 \times 10^{-13} t^{4}$. Some of the data points are averages of several analyses and are weighted more heavily in the polynomial fit. Data are all normalized to 0.70800 for the $E$ and $A$ standard. The vein calcite data from Holes 105, 332B, and $418 \mathrm{~A}$ are shown as solid circles, with bars indicating the $2 \sigma$ uncertainty of the data; the points are plotted at the age of formation of the crust, as determined from fossil and magnetic anomaly data (see relevant DSDP Initial Reports).

450 meters, have ${ }^{87} \mathrm{Sr} /{ }^{86} \mathrm{Sr}$ values which are identical within experimental precision (Table 2), and that approach the sea-water curve very closely (Figure 5 ). Because the ${ }^{87} \mathrm{Sr} /{ }^{86} \mathrm{Sr}$ of present-day sea water is well known $(0.70910$ \pm 6 ) (Veizer and Compston, 1974), the sea-water curve is highly constrained $3.5 \mathrm{~m}$.y. ago. The formal "age" of our Hole $332 \mathrm{~B}$ calcites is $2 \pm 2 \mathrm{~m}$.y., in good agreement with the age of formation of the crust. From these data, it is clear that there was negligible "basaltic" Sr-isotope component in the fluids which deposited these calcites, and that the presence of fluids of sea-water $\mathrm{Sr}$ isotopic composition is demonstrated to at least 450 meters depth in Hole 332B. However, since much of the crustal section at Hole 332B consists of basalt flows, the calcites could have been deposited in shallow flows which were later buried to a depth of 450 meters; thus actual circulation of sea water to this depth cannot be proven. However, the $\mathrm{Sr}$ isotope data (and alkali data) reported in Staudigel et al. (this volume) show that crustal sections of at least 500 meters have interacted with sea water either during accumulation or later as a single unit. Also, oxygen isotope analyses of these calcites (Muehlenbachs, this volume) suggest deposition temperatures of $\sim 20^{\circ}$ to $75^{\circ} \mathrm{C}$. Thus the calcites were deposited at some depth and not at the basalt-sea water interface.

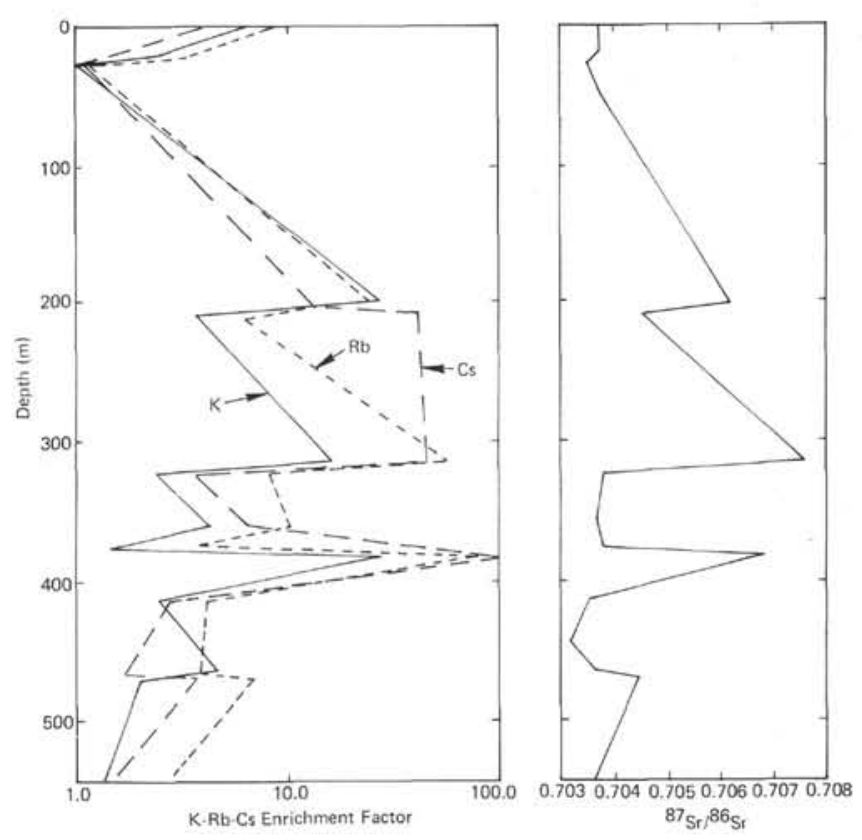

Figure 7. Downhole variations of $K, R b$, and $C s$ concentrations and ${ }^{87} \mathrm{Sr} /{ }^{86} \mathrm{Sr}$ ratios of basalts from Hole $418 \mathrm{~A}$ (Leg 53). $K, R b$, and Cs are plotted as "enrichment factors" relative to the values in fresh unaltered basalt at this site $(K=430 \mathrm{ppm}, R b=0.37 \mathrm{ppm}, \mathrm{Cs}=0.0090$ ppm from Staudigel et at., 1976). Note that very large enrichment factors exist (up to 100 times) and that variations are erratic but correlate well with ${ }^{87} \mathrm{Sr} /{ }^{86} \mathrm{Sr}$ variations (fresh basalt $=0.703$, sea water $=0.709$ ).

A further assumption in this calcite "method" is that calcite preserves its initial $\mathrm{Sr}$-isotopic composition and does not undergo later exchange with either younger sea water or the basalt host adjacent to the veins. Exchange of $\mathrm{Sr}$ in carbonates is a recognized problem and is obviously an important limitation on the establishment of the seawater curve in the first place. Many authors have considered this problem (Peterman et al., 1970; Veizer and Compston, 1974; Dasch and Biscaye, 1971), and the general conclusion is that Mesozoic and younger samples, when not hydrothermally recrystallized, retain their original $\mathrm{Sr}$ isotopic composition. As a further test of this assumption, we analyzed two calcite samples from shallow subbasement depths ( 5 and $9 \mathrm{~m}$ ) at Site 105, drilled in 155-m.y. crust in the western Atlantic. Both the shallow location and the old age should maximize the possibilities for exchange between the calcites and sea water (or sediment pore water). The two calcites have identical ${ }^{87} \mathrm{Sr} /{ }^{88} \mathrm{Sr}$ ratios (0.70692) (Table 2), and the formal "age", derived from the curve in Figure 5, is $172 \mathrm{~m} . \mathrm{y}$. (as opposed to the basement age of $155 \mathrm{~m} . \mathrm{y}$.). The calcite age is in good agreement with the basement age, especially considering that the sea-water curve is not well constrained for ages older than $150 \mathrm{~m}$.y. The Site 105 calcites show no tendency to be too high in ${ }^{87} \mathrm{Sr} /{ }^{86} \mathrm{Sr}$, as would be expected from exchange with younger sea water (or sediments). The value is also not anomalously low, as would be expected from long-term exchange with basalt adjacent to the vein (which will have ${ }^{87} \mathrm{Sr}{ }^{/ 86} \mathrm{Sr} \sim 0.703$ ). 
To summarize the age determination results, vein minerals in the oceanic crust appear to be formed within 5 to $10 \mathrm{~m}$.y of the age of crust formation. Insofar as these vein minerals are related to hydrothermal fluid circulation, the process appears to be relatively short-lived; this is in agreement with the heat-flow circulation model of Wolery and Sleep (1976). Also, the fluids depositing the vein minerals are apparently of sea-water composition (at least with respect to ${ }^{87} \mathrm{Sr} /{ }^{86} \mathrm{Sr}$ ). While our data show that the shallow oceanic crust "seals-up" fairly early, circulation to deeper, slower cooling levels could of course continue for longer periods without detection, provided that it is fed by aquifers that do not deposit vein minerals at shallow (accessible) crustal levels. Furthermore, it is unlikely that any circulation continued after calcite deposition (in the veins we have studied), even though the veins have appreciable permeability (Johnson, this volume). $\mathrm{Sr}$ exchange rates between fluid and calcite, at least at $20^{\circ} \mathrm{C}$, have been determined and these predict complete exchange in times of less than 25 years (Pineau et al., 1973).

\section{INFLUENCE OF CRUSTAL INTERACTIONS ON SEA-WATER ALKALI CHEMISTRY}

From the K-Rb-Cs data of whole rock basalts from Sites 417 and 418 reported by Staudigel et al. (this volume) and plotted in Figure 7, it can be shown that altered basaltic crust is a significant reservoir for alkalies with respect to sea water. Site 417 and 418 basalts show enrichments by a factor of up to 10 in $\mathrm{K}$ and 100 in $\mathrm{Rb}$ and $\mathrm{Cs}$, relative to the original fresh basalt. If the upper 500-meter section sampled in Hole $418 \mathrm{~A}$ is typical of average oceanic crust, the Cs enrichment noted above would represent a crustal Cs reservoir some 25 times that of the Cs reservoir of the whole world ocean. As shown in Figures 3 and 4, the altered whole rocks of Hole 418A are essentially mixtures of fresh basalt and the three alteration components: palagonite, altered glass, and smectite. It is difficult to know at this stage what the proportions of each of these three alteration products are in a typical crustal section, where not only massive basalt is considered, as in Figures 3 and 4, but also all veins, fractures and breccia zones. Because the smectites are considerably more enriched in alkalies than the other alteration products, and because smectite is the typical groundmass alteration of the interiors of basaltic flows and sills, it is reasonable to suppose that this component dominates the alteration signature of a total crustal unit. If this is true, then a simple model for control of sea-water chemistry may be proposed, expressed as the following reaction:

\section{Initial Sea Water + Fresh Basalt $\rightarrow$ New Sea Water + Smectite}

A schematic representation of this model is shown in Figure 7. Addition of fresh basalt alkalies to sea water is modeled as simple mixing of basalt and sea water. Removal of alkalies from sea water by smectite crystallization is modeled as a fractional crystallization process, with assumed constant values of the partition coefficients: $(\mathrm{K}, \mathrm{Rb}, \mathrm{Cs})^{\text {smectite/ }}$ $(\mathrm{K}, \mathrm{Rb}, \mathrm{Cs})^{\text {sea water }}$. The compositions of "analyzed smectites, as discussed above, are represented by mixing lines between the fresh basalt and the pure "equilibrium" smectite. Thus smectite (B) is in equilibrium with present sea water (B); sea-water composition is determined by the bal- ance between basalt addition ( $\mathrm{B}$ moves toward $\mathrm{A}$ ) and smectite removal (B moves towards $\mathrm{C}$ ). Were smectite removal to dominate and drive sea water to $(\mathrm{C})$, then the smectite in equilibrium with this new sea water would be at (C) on the smectite curve, and so on.

$\mathrm{The} \mathrm{Rb} / \mathrm{Sr}$ isochron data on Leg 53 smectites (Figure 1) suggest that these smectites have been closed systems for $110 \mathrm{~m} . \mathrm{y}$. Some open-system behavior is possible, within the scatter of the data, but, as argued above, most of this scatter is believed to be a result of basaltic host impurities in the smectites. If the smectites originally crystallized in equilibrium with sea water, it may then be argued that the alkali contents of the smectites retain a record of the alkali contents of the sea water from which they crystallized; i.e., the smectites may be paleo-sea water-alkali recorders. The partition coefficients of trace elements such as rubidium and cesium are probably dependent principally on temperature and phase composition; the partitioning of potassium, which may be a pseudo-stoichiometric component in smectite, may not be as useful for determining fluid compositions. A further complication is that it is difficult to derive the composition of the pure smectite end-member from the impure smectites which are analyzed. However, as can be seen from Figures 3 and 4 , the segments of the basalt-smectite mixing curves nearest the pure smectite end-member are parallel to lines of constant $\mathrm{K}-\mathrm{Rb}$ and $\mathrm{K} / \mathrm{Cs}$ ratio. Thus it should be possible to use smectites to determine paleo-K/Rb and $\mathrm{K} / \mathrm{Cs}$ ratios of sea water, even if absolute concentations are not attainable. As an initial attempt at this, we used a smectite from Hole 332B (3.5 m.y. old) to empirically calibrate the alkali partition coefficients between sea water and smectite. Applying these partition coefficients to the Hole 418A smectites leads to $\mathrm{K} / \mathrm{Rb}$ and $\mathrm{K} / \mathrm{Cs}$ ratios for the oceans $110 \mathrm{~m} . \mathrm{y}$. ago which were lower than present by factors of 1.4 and 4.5, respectively. A great deal more needs to be done with respect to evaluating temperature and composition effects on the partition coefficients, as well as testing for consistency on an intra- and inter-site basis. However, the concept is encouraging, especially since a direct test for closed-system behavior is available through the use of $\mathrm{Rb}-\mathrm{Sr}$ isochron relationships.

\section{ACKNOWLEDGMENTS}

This work was supported by ONR, Grant N-00014-75-C0291. We are grateful for discussions with $\mathrm{K}$. Muehlenbachs and a preprint of his paper. E. Boyle was very helpful in clarifying our ideas regarding the sea water-alkali model.

\section{REFERENCES}

Brass, G.W., 1976. The variation of the marine ${ }^{87} \mathrm{Sr} /{ }^{86} \mathrm{Sr}$ ratio during Phanerozoic time: interpretation using a flux model, Geochim. Cosmochim. Acta, v. 40, p. 721-730.

Dasch, E.J. and Biscaye, P.E., 1971. Isotopic composition of strontium in Cretaceous-to-Recent pelagic foraminifera, Earth Planet. Sci. Lett., v. 11, p. 201-204.

Donnelly, T.W., Francheteau, J., et al., 1977. Mid-ocean ridge in the Cretaceous, Geotimes, v. 22, p. 21-24.

Flower, M. J., Salisbury, M. H., et al., 1977. Cretaceous crust sought, Geotimes, v. 22, p. 20-22.

Hart, S.R. and Brooks, C., 1977. The geochemistry and evolution of early Precambrian mantle, Contrib. Mineral. Petrol., v. 61, p. $109-128$. 
Lister, C.R.B., 1972. On the thermal balance of a mid-ocean ridge, Geophys. J. Roy. Astron. Soc., v. 26, p. 515-535. 1974. On the penetration of water into hot rock, Geophys. J. Roy. Astron. Soc., v. 39, p. 465-509.

Peterman, Z.E., Hedge, C.E., and Tourtelot, H.A., 1970. Isotopic composition of strontium in sea water throughout Phanerozoic time, Geochim. Cosmochim. Acta, v. 34, p. $105-120$

Pineau, F., Javoy, M., and Allegre, C.J., 1973. Etude systematique des isotopes de l'oxygene, du carbone et du strontium dans les carbonatites, Geochim. Cosmochim. Acta., v. 37 , p. $2363-2377$,

Spooner, E.T.C., 1976. The strontium isotopic composition of sea water, and sea water-oceanic crust interaction, Earth Planet. Sci. Lett., v. 31, p. 167-174.
Talwani, M., Windisch, C.C., and Langseth, M.G., 1971. Reykjanes Ridge Crest: a detailed geophysical study, J. Geophys. Res., v. 76, p. 473.

Veizer, J., and Compston, W., 1974. ${ }^{87} \mathrm{Sr} /{ }^{86} \mathrm{Sr}$ composition of sea water during the Phanerozoic, Geochim Cosmochim. Acta., v. 38 , p. 1461-1484.

Williams, D.L., von Herzen, R.P., Sclater, J.G., and Anderson, R.N., 1974. The Galapagos spreading centre: lithospheric cooling and hydrothermal circulation, Geophys. J. Roy. Astron. Soc., v. 38 , p. 587-608.

Wolery, T.J. and Sleep, N.H., 1976. Hydrothermal circulation and geochemical flux at mid-ocean ridges, J. Geol., v. 84, p. 249-275.

York, D., 1966. Least-squares fitting of a straight line, Canadian J. Phys., v. 44 , p. 1079-1086. 